DE DE GRUYTER OPEN
Journal of Intercultural Management

Vol. 7, No. 3, September 2015, pp. 143-155

DOI 10.1515/joim-2015-0026

Joanna Wiśniewska-Mikosik ${ }^{26}$

University of Social Sciences

\title{
Organizational Culture as a Variable that Determines Effective Cross-cultural Management
}

\begin{abstract}
Traditionally, organizational culture is strongly connected with the culture of a particular country or a region. In Poland more and more organizations have been paying attention to it since the beginning of transformation. Managers and employees are increasingly putting an emphasis on the intentional development of culture in their own business, also during trainings, as this is an important element of organizational success. However, in Poland, which is a conglomerate of various cultural patterns, specifying one common reference point as the main determinant and the basic element of organizational culture in Polish companies is not easy. The transfer of Polish cultural patterns into a different area usually creates problems. Polish organizations also struggle with adopting other cultural patterns. Globalisation and the process of "shrinking" the world lead to the development of international organizations. As a result, new types of organizational culture can be observed. This can be called a blend of cultures or multiculturalism. Managing in such conditions is cross-cultural management. Organizations, managers and employees have to act in such a way in order to, on the one hand, maintain their cultural identity, on the other hand, skilfully adapt and implement elements from other cultures. This gives organizations an opportunity to be creative and competitive in today's market.
\end{abstract}

Key words: organizational culture, intercultural management, multiculturalism, culture mix, globalization

\section{Introduction}

When we reflect on the influence of culture on management companies, we usually have in mind the impact of values and standards existing in the country

\footnotetext{
${ }^{26}$ jwismik@gmail.com
} 
and affecting the behavior of people working in various types of institutions, including business organizations. In theory these values and standards underlay different processes and procedures in different nations and countries. Activities of an economic nature and management will therefore, according to this theory, differ depending on the culture of the country. Often colloquially we talk about the fact that "Poland does not have a tradition of good governance", or that "Poles are not able to work well and organize work." Both of these statements have some elements indicating cultural determination in Poland probably emanating from Poland's education system.

Let us begin by defining the term "culture". Culture is generally the product of human activity, tangible and intangible, valued and recognized within the community [Szczepański 1972]. This community may be different in terms of culture theory. This means in terms of the products of thoughts and actions, values and practices that are recognized and accepted by the community and that have gained importantance to its members, thereby setting behaviors considered to be mandatory [Szczepański 1972, p. 83].

\section{Culture as a variable}

\section{Culture as an independent variable}

In many comparative studies on organizations that have been very popular lately, (so-called "cross-national research" or "comparative management"), culture is often regarded as an independent variable, i.e. an external factor which directly affects and determines behaviors inside the organization, behaviors of both the employees and the managers in a specific country. This is a factor that practically remains unchanged. It is a factor derived from one's place of birth and upbringing. An individual born and raised, for example, in Japan would work according to the ethos of work of Japanese national culture. The studies carried out with this approach usually focus on the analysis of management and employee attitudes in different countries [cf. Smircich 1983; Hofstede 1980, 2000; Solarz, 1985; B. Cichomski, W. Morawski 1988; Morgan 1997, pp. 128-136; Fukuyama 1997; Hampden-Turner, Trompenaars 1998], or they compare business activities [cf. Berger 1994].

Culture is seen here nearly as a synonym of the studied country. It is very important to analyse values and norms adopted in a specific country and take into account religion in that country [Berger 1994, Korzhov 1999]. The literature on this issue may be divided into two groups:

- the first group includes studies on relations between culture and, for instance, the structure of the organization,

- the second group involves studies focused on the similarities and differences in the attitude of managers, employees and entrepreneurs, members from different cultures [Smircich 1983, p. 343, Konecki 1985, pp. 245-248]. 
Comparative studies are usually based on the outcomes of polls and questionnaires. They are usually focused on studying a particular type of problems only, including the attitude to work, work or career satisfaction which, as a result, limits to some extent the area of observations. Thus, this type of studies enables to get to the values and norms that differentiate, for example, the ethos of work in different countries or employee orientations and attitudes, however, it does not allow to see broader relationships. It seems obvious that the differences in behaviours of employees in Japanese, American or Polish companies will be obvious even to a researcher who is not too inquisitive. The culture of a particular country lies at the bottom of these differences, i.e. the values and norms that occur in it, which are an element passed down from generation to generation in the process of upbringing.

For example, after Hampden-Turner and Trompenaars [1998], we can distinguish four elementary dimensions that differentiate the group of basic values:

a) universality - particularism, here it is worth asking the following question: Do the rules that we are able to arrange in a systematic way control the actions taken by managers? Or perhaps every single case of making decisions, according to the author's assumptions, should be considered in a separate and independent way?

b) analysis - synthesis, it raises another question: Do managers consider the possibility of analysing each case separately? Do they consider the possibility of combining elements in a new whole to form new values based on them?

c) individualism - collectivism, what is more important: an individual with his or her development, individual rights or the community, the group and the company are more important?

d) equality - hierarchy: Is it more important for an organization to treat its employees as equal partners in the process of its development or more attention is given to highlight the hierarchy, the power of those who are in charge, and respect for such a situation?

Below is a short deliberation on the consequences of the dominating role of individual solutions:

A strong attachment to "universalism" as a complete opposite of particularism gives guidance for managers to use the rules that are considered to be generally accepted.

On the other hand, aiming at the "analysis", in contrast to synthesis, causes that employees are treated as "human resources" comparable to the sources of capital or resources. They are not the subject of the process. This interpretation leads towards a management style defined as management by objectives [HampdenTurner, Trompenaars 1998, p. 40, 44]. The core of analytical objectives is to aim the activities of the organization at effectiveness whose basis direct consequence is profit. Extreme analytical aims create favourable conditions for the development of bureaucracy. 
When we deal with a predominance of individualistic values over the collective values, both of which determine the ways of rewarding and motivating employees, we notice dominance mainly in the area of motivating and rewarding employees such as promoting, award bonuses and rewards for individual achievements, an individual assessment of employees concerning the tasks they carried out, methods of selection and recruitment of employees, we deal with a situation of disturbing internal relations among employees.

These are only a few selected antagonisms that occur in the organization, they have their roots in the culture of the country from which a particular organization comes from.

Figure 1. Organizational culture as an effect of the cultural influence of a specific country

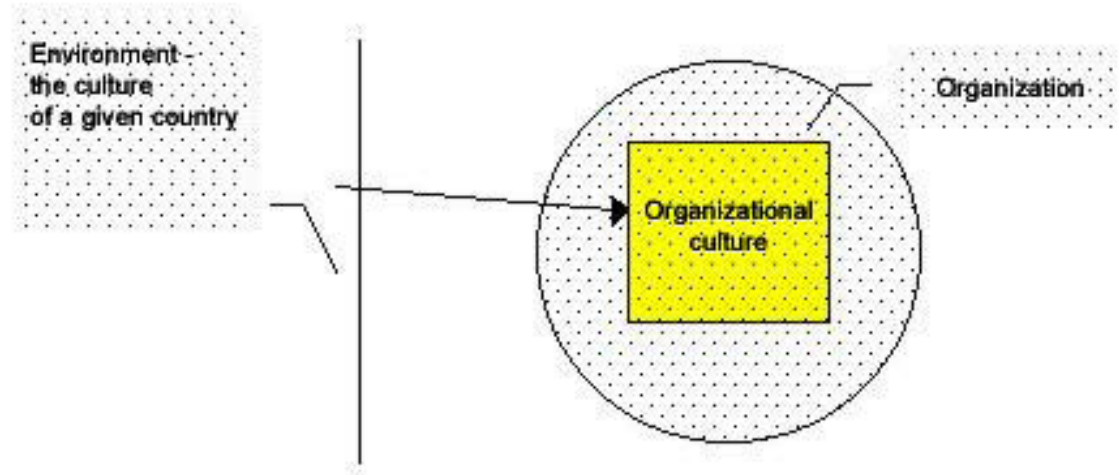

Source: Konecki.2000.

Certainly, the approach presented above is only one of the aspects dedicated to perceiving organizational culture as a variable. Like all attempts of defining and developing a framework for the whole range of issues related to organizational culture, also this approach has its supporters and critics. The opponents of this approach claim that both the context of work and individual interpretations in which it is difficult to avoid the element of latitude and a subjective choice made by the participants of the work process have no chance of being presented properly. Therefore, actual actions taken by employees in an organization are considered in a very limited way in this type of analysis. Usually selected for the presented approach, quantitative methodology, which aims mainly at studying the objectified cultural aspects and behaviours, leads to the mentioned limitations to a great extent. 
Supporters of treating culture as an independent variable think that the organizational structure and the outcomes of activities of a particular organization can be explained from the angle of specific features of a given culture [Redding 1994].

An example of this type of thinking is a work by R. Dore [1973] in which the author compares British and Japanese electronics companies. He suggests that "different assumptions on human nature" in both cultures cause the development of completely different relations between managers and employees.

\section{Culture as a dependent variable}

Since culture has more than one name, so does organizational culture. It tends to be regarded as an element of organization that is dependent on other organizational elements, thus, it is specified as a dependent variable. This means that it is determined by other factors [Smircich 1983] such as transaction costs, property rights [Jones. 1983; Wilkins, Ouchi 1983] or actions taken by entrepreneurs or organizational leaders. In this view, organizational culture is a creation of the internal environment of a given organization.

Figure 2. Culture as a dependent variable (see also Example 2)

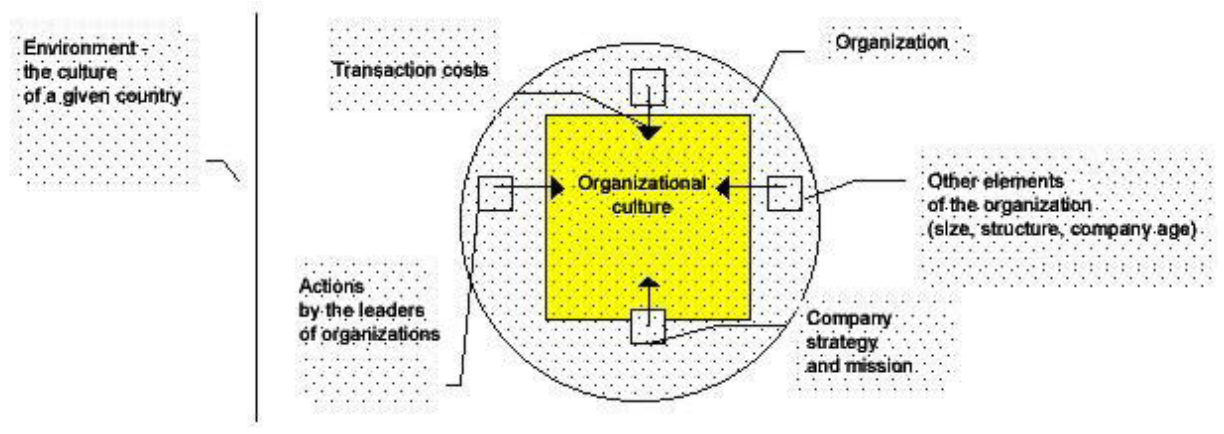

Source: Konecki.2000.

When a particular culture with its norms and values is formed in an institution, it can operate as it was bureaucratic rules and procedures:

"The use of sophisticated socialisation programmes in a professional training for employees can be considered as a way to economize on transaction costs, that is why the internalization of norms and values provides employees with a common language through which they carry out activities and regulate exchange relations" [Jones 1983, p. 464]. The exchange in organizations, for example, between employers and employees may be controlled not only by market mechanisms such as salary or a bureaucratic mechanism in the form of provisions, but also by a cultural form of regulations which includes values and norms [Wilkins, Ouchi 1983]. The employees who participate in the process of economic exchange in the labour market are 
socialised in such a way that there is no need to supervise them during work. They accept and recognise particular norms and values and, as a consequence, social norms determine the high quality of work, the good organization of work, complete loyalty to the company, etc.

The cultural form of regulations is in this case a consequence of transaction costs and a variable dependent on the exchange process. Employers, if it is possible in specific conditions, use the cultural form of regulations because this is a cheaper alternative for the bureaucratic form. The only cost is generated here by intense trainings for employees at a stage of shaping their relations during which they are subject to certain educational procedures that develop their new values and everyday habits. In an extreme case they also result in changing participants' personality.

A positive effect of using this form of regulations, determined also as a process of re-upbringing employees, is usually the high quality of performance and complete loyalty of such employees to the company.

Certainly, this approach has its critics as well. They claim that the presented model, compared to the model previously presented, takes into account the internal dynamics of organizational culture only in a slightly bigger extent.

In this view, organizational culture is still regarded as one of many elements in the organization or sometimes as a variable intermediating in the correlations between other organizational variables.

For example, the study presented by Pascale shows that the size of the organization has a bigger impact on the intensification of direct communication which is regarded as a property of organizational culture rather than the culture of a given country.

The bigger the organization is, the more this element becomes less significant. This concerns both Japanese and American companies [cf. Pascale 1978, pp. 107-108].

According to the critical arguments, the importance of the cultural influence of a specific country on the operation of the organization is usually diminished here. In this view employees are generally treated as those who submissively carry out their tasks because of external influences [Epstein 1990, p. 90].

An individual is not the main area of interest for researchers.

\section{Culture as an autonomous entity}

An alternative for the two models presented above is the third model. This is an analytic model of organizational culture also called an indeterministic model of analysis [Smircich 1983; Konecki 1985, Morgan 1997, pp. 146-152]. Culture is regarded as an autonomous entity, independent both of the influence of culture in a specific country and other elements of the internal environment in a particular organization which are independent of it. Despite its constructive autonomy, this model seems to be the least popular among researchers. It is rarely used in empirical studies. 
Culture is a form of expression of human consciousness here. In this view culture and the organization mean the same. These terms are treated as synonyms. Studies based on this view focus on learning and experiencing the organization that is a kind of a subjective experience for each participant. The organization is a social construct here [cf. K. Konecki 1992]. The regular qualitative methods are used here and case studies are the most common tools [cf. K. Konecki 2000, pp. 126143]. The research activities aim mainly at looking for the subjective definitions of situations and different aspects of organizations [Turner 1971]. To achieve this objective, researchers often spend much time together with the observed persons to be able to express their point of view on the events and issues that occur in the organization. By doing so, it is possible to show the processes of interaction occurring in the organization such as fight, games, manipulations, negotiations. These processes have a direct impact on the shape of the organization but also on its constant changes. In this view the organization is a process.

Figure 3. Organization as a cultural phenomenon, the indeterministic model of analysis of organizational culture (see also the end of the chapter, Example 3)

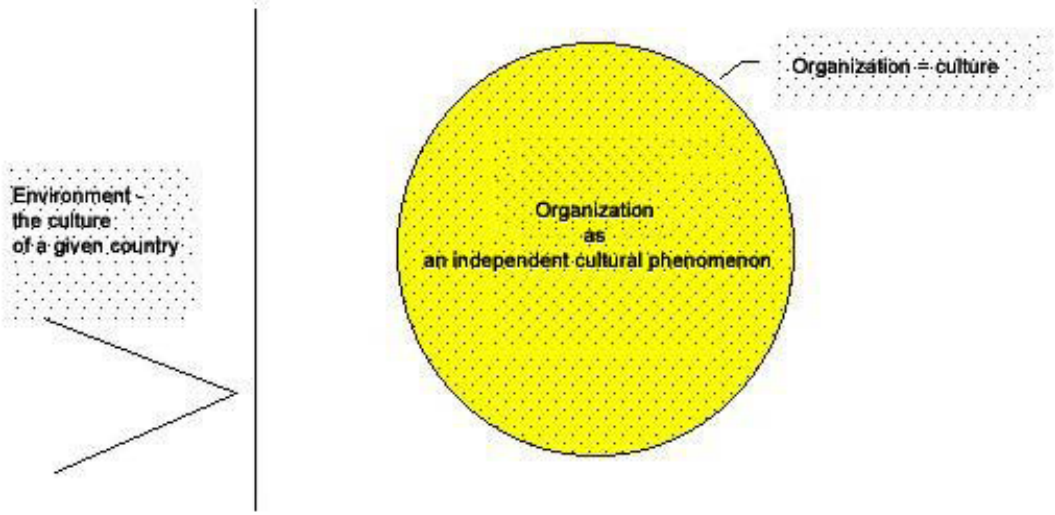

Source: Konecki 2000.

However, critics of this approach point out the elementary, in their opinion, mistake that lies at its basis. It focuses, in their view, mainly on the description of organizational culture and not on explaining what it is and what role it plays. The main subject of deliberations in this approach is a focus on concepts specific for particular cultures, not on the concepts of the universal approach. The researchers who support this view tend to use the case study for observations, i.e. usually individual organizations or enterprises, which in their opinion prevents from generalisations and even a wider diagnosis of the term „culture”. 
Taking into consideration the diversity of the analytical approaches outlined above and their achievements in studying organizational culture, it can be stated that organizational culture is the influence that is developed both in the organizational environment (culture as an independent variable, Fig. 1) and also inside the organization (culture as a dependent variable, Fig. 2) as well as "in human mind" (indeterministic model of analysis, Fig. 3).

To sum up, organizational culture would cover the systems of values and norms which are shared collectively in the organization and are often derived from the organizational environment, common and often sub-conscious assumptions and rules related to them which are created by the members of the organization, as well as the whole internal symbolic operational sphere of the organization. The symbolic sphere includes the organizational language, ideas, myths, beliefs, systems of knowledge, rituals that occur in the organization. The term "organizational culture" defined by us in this way can fulfil a function of integrating the description and the analysis of an organization or an enterprise.

\section{Figure 4. The integrated model of organizational culture}

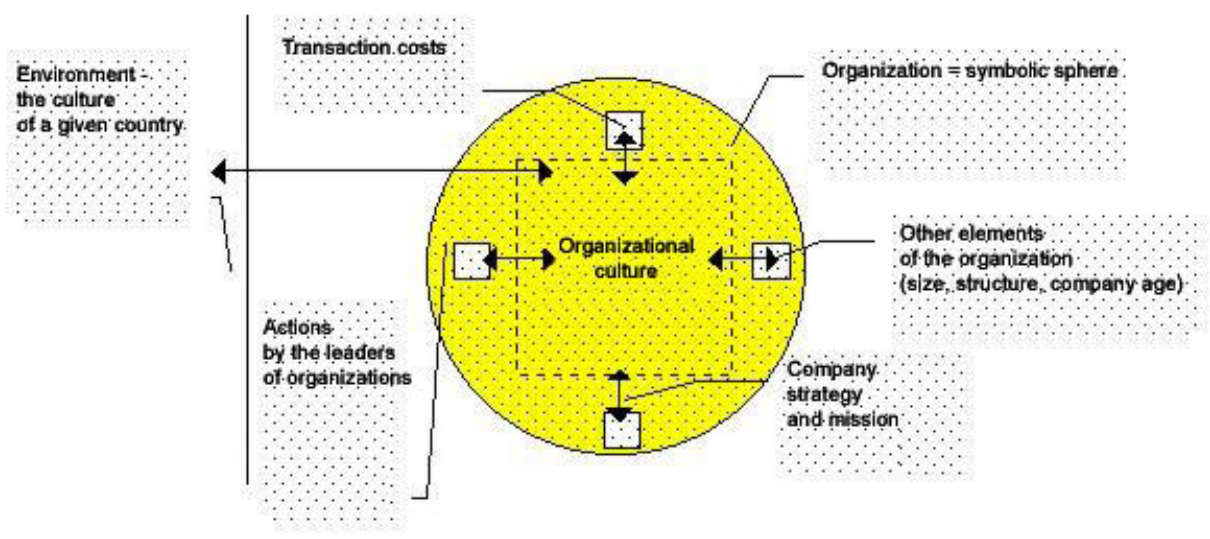

Source: Konecki 2000.

We go beyond the limits of the model treating organizational culture as an independent variable and a dependent variable, as well beyond the indeterministic model of analysis. These three models can be used together and globally. These models were formed based on studies and analyses, thus, they reflect the empirical state of an organization operating in the cultural dimension. Organizational culture depends both on the culture of a specific country and the internal elements of an organization. It can also be partially independent of those two aspects due to the autonomy of human actions that occur in organizations. Organizational culture may 
even have an impact on the functioning of some elements in the organization and the culture of a specific country, for example, some companies affect the lifestyle (Fig. 4). Thus, organizational culture can be perceived from three points of view and these points of view show the real dynamics of developing organizational culture, which is proved by the empirical studies mentioned earlier (see also: Examples at the end of the chapter). Making a triangulation, i.e. approaching the problems from three points of view at the same time, we create the fourth integrated model of analysis that is in fact a synergic result of the previous three points of view (Fig. 4).

When discussing organizational culture from a sociological perspective, we focus on the group and community aspect of developing and maintaining this culture, its internal contradictions related to the hierarchy as well as the structure and the social bond. In a scientific discipline called "organization and management" science it is thought that organizational culture is strictly related to competent management and managing a formal organization. The instrumental area of activities is a consequence of values adopted, norms of a particular organization [Sikorski 1986]. The company success may be credited to organizational culture which is intentionally shaped by the management (educational and state institutions as well). Furthermore, this success may relate to the skills of instrumental use of these cultural elements, which are beneficial for modern organizational techniques and strategies. The description of organizational culture according to our definition shows the role played by the expressive and interactive elements of rational organizational actions, often ignored and treated as a folk background by organizational practitioners and the researchers studying organization and management [cf. K. Konecki 1992a, pp. 165-175]. It turns out that individual and autonomous actions, i.e. independent of external factors, play an extremely important role in organizations.

Summing up, it can be stated that companies obtain not only capital, energy, material, people and information from their environment but also culture in the form of norms, beliefs, stereotypes or symbols. These inputs are developed inside the organization and processed into outputs such as products or services which, as a result, become an element of feedback with inputs. The culture of a society which is transformed in the company is a material from which the company organizational culture is made (see Fig. 4). It is also contained in outputs, i.e. products, services, the company image that reflects it in the awareness of customers and contractors and in the organizational identity, i.e. the conceptions of members of the organization of what is distinctive, unique and constant in their company and what, in their opinion, the important external partners of their organization think about the things which are distinctive, unique and constant. Thus, the organizational culture of a company goes beyond the company to the environment that is changed under its influence in the cultural aspect (customers change their tastes or customs and habits). Companies change the culture of the societies of their customers through their 
products and adverts. For example, some products such as a Walkman, a mobile phone or a visual product advert promoting new styles of dressing, consumption, spending free time, hedonistic values changed permanently our culture of everyday life. Thus, the culture of a given country cannot be regarded as a variable affecting only the operating of a company and its organizational culture in only one way. It is also affected by business activities in the economic market.

\section{How can the organizational culture that plays the role of a variable affect cross-cultural management in the organization?}

Culture perceived in the perspective of cross-cultural comparative studies on management is an independent variable affecting the organization [Kostera 1996, pp. 63-65]. Taking into account this approach, it is defined in functional categories and is a background which has an impact on the management process. Studies on the national styles of leadership and management as well as comparative studies on the impact of cultural background on organizations are based on this approach.

In the previous sections various models of regarding organizational culture as a variable were pointed out. However, it has been recently argued more and more frequently that today organizations are understood mainly as symbolic actions, forms of human expression, the output, the effect of cognitive undertakings or a sign of community involvement. In the context of the paradigms above, a change in the perspective of perceiving and defining organizational culture is gradually taking place.

Business organizations are not just economic undertakings anymore but the psychological, social and symbolic dimensions of their operation are pointed out [Sułkowski 2005].

Assuming that organizational cultures have to be related to the cultures of societies, is it reasonable to expect an exchange of elements among them?

The majority of researchers (after: Sułkowski 2005) assume that the transfer of values and norms from the culture of the society to the organizational culture is taking place.

Certainly, one cannot deny that a reverse process may be taking place as well but, as it can be assumed, its intensity is much lower.

Traditionally, organizational culture is strongly connected with the national culture of a particular country. In fact, it is difficult to find one type of culture that is only used in the operating, live organization. In live organizations the mixed type is usually used. Poland is a particularly interesting example of a huge diversity of cultural influences from the organizational environment. Since it is situated in the centre of Europe, different cultural patterns can be found there. This is usually a consequence of our history and a hangover from the period of partitions. S. Kurowski, who studied this issue in terms of economic issues, explains that 
even today significant differences can be found among organizations located, for example, in the provinces of Białystok, Poznań or Cracow.

The transfer of Polish cultural patterns into a different environment is not always easy. On the other hand, adopting different cultural patterns is difficult for Polish organizations. As a result, many foreign organizations because of the cultural factors are more willing to employ young, inexperienced graduates who are more impressionable than the experienced but shaped in different cultural patterns specialists. There are various organizational cultures in the world. S. Ronen distinguished the following culture circles:

- Anglo-Saxon (US, Canada, the UK, New Zealand, Australia, Ireland);

- Germanic (Germany, Austria, Switzerland);

- Nordic (Sweden, Denmark, Norway, Finland);

- Middle Eastern (Turkey, Greece, Iran);

- Arabic (Saudi Arabia, Oman, Kuwait, the United Arab Emirates, Bahrain, Abu Dhabi);

- Far Eastern (Thailand, Taiwan, Indonesia, Vietnam, the Philippines, Hong Kong, Singapore, Malaysia);

- Latin American (Colombia, Peru, Mexico, Chile, Venezuela, Argentina);

- Latin European (France, Belgium, Italy, Spain, Portugal);

- non-standard cultures (Brazil, Japan, India, Israel).

The presented classification is old since the results of the research were published in 1986. Since then, changes have been taking place successively.

Changes in the world, including the development of international and multinational organizations, resulted in establishing a new type of organizational culture. This culture can be called a culture mix or according to the literature on the subject - interculturality or multiculturalism, and the management related to it is intercultural management.

As J.F Stoner says, multiculturalism can be defined as a view that there are many different cultural means and factors which are very important for organizations and that people from different backgrounds may coexist and be accepted in the organization. Multiculturalism is usually defined as cultural factors such as ethnic origin, race, sex, fitness, sexual orientation. However, according to Koźmiński, crosscultural management is focused on organizational behaviours in international systems, buman interactions from more than one culture operating within organizational roles.

Cross-cultural management is based on the assumption that culture has an impact on the way of how such roles are played. Thus, this is a kind of "an operation on culture". It involves taking ad-hoc actions in the social sphere of the organization and intentional aiming to change its subculture in such a way that it could manage multiculturalism better. 


\section{Conclusions}

In a situation when more and more organizations have international staff and international owners, such actions must be taken to manage the existing diversity skilfully. Managers and employees face the problem how to function in order to, on the one hand, maintain their cultural identity, and on the other hand, adopt the most important things from different cultures that will help the organization to be competitive and creative. Ethical issues are strictly related to culture matters. However, due to the fact that business ethics is a separate problem, this issue was only mentioned [Kisielnicki 2008].

Summing up the deliberations in this article, I have the impression that they are still an introduction for further discussion on the typology of models of organizational culture as a variable in the face of challenges related to the transformations which are a consequence of cross-cultural management.

\section{References}

Epstein C. (1990), The Cultural Perspective and the Study of Work [in:] Erikson K., Vallas S., The Nature of Work. Sociological Perspectives, Yale: Yale University Press.

Fukuyama F. (1997), Zaufanie. Kapitat spoteczny a droga do dobrobytu, Warszawa: PWN.

Hampden-Turner Ch., Trompenaars A. (1998), Siedem Kultur Kapitalizmu, USA, Japonia, Niemcy, Francja, Wielka Brytania, Szwecja, Holandia, Warszawa: ABC.

Hofstede G. (1980), Culture's Consequences. International Differences in Work Related Values, Beverly Hills, London: Sage Publications.

Hofstede G. (2000), Kultury i organizacje. Zaprogramowanie umystu, Warszawa: PWE.

Jones G. (1983), Transaction costs, Property Rights and Organizational Culture: An Exchange Perspective, "Administrative Science Quarterly", Vol. 28, pp. 454-467.

Konecki K. (1985), Kultura organizacyjna, „Studia Socjologiczne”, 4-3: 237-258.

Konecki K. (1992), Nowi pracownicy a kultura organizacyjna. Studium folkloru fabrycznego, Lódź: Wydawnictwo Uniwersytetu Lódzkiego.

Konecki K. (1994), Kultura organizacyjna japońskich przedsiebiorstw przemystowych, Łódź, Wydawnictwo Uniwersytetu Lódzkiego.

Konecki K., Frączak-Konecka E. (1998), Spoteczne tworzenie strategii džiałania pržedsiebiorstw przemystowych. Konsekwencje prywatyzacji, „Studia Kupieckie”, 1.

Konecki K. (2000), Studia ₹ metodologii badań jakościonych. Teoria ugruntowana, Warszawa, PWN.

Korzhov G. (1999), Historical and Cultural Factors of Enterpreneurship Re-Emergence in Post-Socialist Ukraine, "Polish Sociological Review", 4: 503-532.

Morgan G. (1997), Obrazy organizacji, Warszawa: PWN.

Pascale R. (1978), Communications and Decision Making across Cultures: Japanese and American Comparisions, "Administrative Science Quarterly", Vol. 23, pp. 91-110. 
Sułkowski Ł. (2005), Czy warto zajmować sie kultura organizacyjna? [in:] Sułkowski Ł., Epistemologia w naukach o zarzadzaniu, PWE, Warszawa.

Sułkowski Ł. (2002), Kulturowa żmienność organizacji, PWE, Warszawa.

Sweeney E.P., Hardaker G. (1995), The Importance of Organisational and National Culture, „European Business Review", INTERNET - sweeney.htm.

Thompson K.R., Luthans F. (1990), Organisational Culture. A Behavioural Perspective [in:] Organisational Climate and Culture, 1., B. Schneider (Ed.) Oxford UK: Jossey-Bass.

Schneider B. (ed.), Jossey-Bass O., van Maanen J. (1998), Tales of the Field. On Writing Ethnography, University of Chicago Press, Chicago.

Weber M. (2002), Gospodarka i spoteczeństwo: zarys socjologii rozumiejacej, PWN, Warszawa.

Whiten A., Goodall J. et al. (1999), Cultures in Chimpanzees, „Nature”, No. 399.

Whyte W.F., Greenwood D.J., Lazes P. (1991), Participatory Action Research: Through Practice to Science in Social Research [in:] Participatory Action Research, Whyte W.F. (ed.), Sage, New York.

Szczepański J. (1972), Elementarne pojecia socjologii, Warszawa: PWN.

Turner B. (1971), Exploring the Industrial Subculture, London: The Macmillan Press Ltd.

Wilkins A., Ouchi W. (1983), Efficient Cultures. Exploring the Relationship between Cultures and Organizational Performance, "Administrative Science Quarterly", Vol.28, pp. 468-481.

Quinn R.E., Cameron K.S. (1999), Diagnosing and Changing Organizational Culture Diagnosing and Changing Organizational Culture, University of Michigan Business School, Michigan.

Wiśniewska-Mikosik J. (2013), Metodyka badań nad kultura organizacyjna [in:] Metody zarzqdzania kultura organizacyjna, (eds.) E.Sułkowski, Cz. Sikorski, Difin, Warszawa. 